\title{
The nutritional balance of advantage and disadvantage
}

\author{
By M. PүкE, Glenochil Research Station, The Distillers Company Limited, Menstrie, \\ Clackmannanshire
}

Problems that occur from the use of additives in food and the presence of contaminants that stem from their employment can be discussed from several points of view. Earlier papers in this symposium have concentrated primarily on the analytical difficulties of determining small concentrations of complex organic chemicals, on the toxicological hazards arising from the presence of trace concentrations of various compounds in food, and on the assessment of rational limits for permissible levels in diverse commodities and in the diet as a whole. The purpose of this paper is to consider the implications of the use of additives and of the inevitable hazards inherent in such use on the nutritional status of the community in which they are used.

\section{Food, health and income}

There are two main avenues to the approach to health, of which nutrition is a part. One is by way of biochemistry, the other by way of natural history. During the last two generations or so most scientific study of nutrition has concentrated on biochemistry. On the positive side there have been the major advances in food chemistry, which make it possible to define a nutritionally adequate diet in terms of its chemical components, traditionally grouped as those mainly concerned with energy production the amino acid components of protein, the list of organic compounds required in small or trace amounts, which are included under the designation of vitamins, and others. Side by side with the elucidation of the chemical composition of the diet has come understanding of the biochemical function of many of its separate components. This is the positive corpus of knowledge constituting nutritional biochemistry. The negative side, admirably reviewed in the recent book edited by Roe ( 1970 ), is concerned with toxic compounds. Today's meeting has concentrated on various substances added to food for technical reasons and described as 'additives', or on those accidentally gaining access to the diet and consequently to be defined as contaminants. It could equally well have dealt with the numerous substances naturally present in different types of foodstuffs, which are toxic either to every consumer or to a particular category as, for example, the lactose of milk to people who are lactose-intolerant.

But important though the biochemical principles of nutrition are and equally important though it may be to ensure that proper attention is directed to the metabolic aspects of food safety, there is a further area of consideration which must be 
taken into account by those concerned with the nutritional well-being of human communities. I refer to the natural history of the species. Human behaviour is such that any assessment of the harm likely to accrue from the presence of a certain concentration of an additive or of a contaminant must be linked with a parallel assessment of any economic significance which such additive or contaminant may possess.

The close association between food, health (which in this context could be broadly equated with nutritional status) and income has been demonstrated by several authors. Seebohm Rowntree pointed out three times, first in I 899 (Rowntree, 1903), then in $193^{6}$ (Rowntree, 194I) and finally in I950 (Rowntree \& Lewens, 195I), the intimate effect which poverty exerts on nutrition. Orr, in his classic study of 1152 working-class families in 1935 (Orr, 1936), showed that in the lowest economic group comprising $10 \%$ of the British population, representative of 4500000 people, the diet failed to provide enough calories, protein, vitamin A, vitamin $\mathrm{C}$, iron and calcium required for proper nutrition, and that as income increased so did the nutritional content of diet approximate more and more closely to adequacy. Finally, I would cite the study of Wittmann, Moodie, Fellingham \& Hansen (1967) among Cape coloured families in Bontheuwel near Cape Town, which demonstrated not only the relationship of income or, if you prefer, its reciprocal, poverty, with such conventional indications of nutritional status as the heights and weights of children and the albumin content of their blood, but also correlated it with less frequently recorded but equally significant criteria such as the incidence and severity of their bouts of diarrhoea and the frequency of their infestation by lice.

I cite these few examples from the literature to illustrate the difference in the conclusions to be drawn about nutritional status and its assessment when the natural history of the community is taken as a starting point rather than the biochemistry of the mammalian tissues of which its individual members are composed.

\section{Additives and income}

Although nutritional status has been correlated in quantitative terms with income by those investigators I have quoted and many others, it cannot be claimed that physiological well-being can be charted in relation to money with as high a degree of precision as is purported to be shown in the tables of recommended dietary allowances. While it has frequently been shown that a particular degree of malnutrition can be relieved on the one hand by a quantitative injection of added vitamins and amino acids or, on the other hand, by a measured allowance of money, precise charts showing the correlation of these two kinds of supplement are seldom attempted. Nevertheless, while accepting the validity of the evidence upon which the Swann Committee of I968 (Swann, I969) condemned the use of penicillin, chlortetracycline and oxytetracycline as additives in poultry foods, which led to their being forbidden in Great Britain by legislation (Statutory Instrument, 1971) under the Therapeutic Substances Act of 1956 (Public General Acts, 1970), it is relevant to take account of the fact, as reported by Walters ( $197 \mathrm{I}$ ), that the use of zinc 
bacitracin, nitrovin and flavomycin, together with quinoxaline, arsanilic acid and 3-nitro-4-hydroxyphenyl arsonic acid, which may still be employed as additives in poultry feed, may be expected to produce an improvement in live-weight gain of about $5 \%$. The cost of the feed is the single most important factor governing the cost of the poultry meat produced. The use of additives improves the rate of food conversion by $3-4 \%$ and, according to Walters ( $197 \mathrm{I}$ ), half the increased yield can be accepted as a nct reduction in the cost of the meat produced. It would appear therefore, that, in considering any possible harmful effect arising from the additives fed to the chickens, equivalent attention must be given to the further availability to the community of animal protein, because of even further reduction in cost, that recently-applied science has already enabled to be the cheapest form of meat.

To reach a balanced view of the problems presented by additives and contaminants, nutritionists must make similar assessments of the economic contribution made by the use of organomercury compounds to suppress seed-borne fungal discases of cercals. Laverton ( 1962 ), for example, has pointed out that the treatment of $80-85 \%$ of the cereal crops sown in the United Kingdom has reduced the spoilage of wheat, barley and oats from $33 \%$ affected by smut in I $92 \mathrm{I}$ to less than $\mathrm{r} \%$ in $\mathrm{I} 96 \mathrm{I}$, representing an increase in yield of $6-8 \%$, equivalent to 900000 tonnes of grain. Similarly, the use of the insecticides dieldrin and $\gamma$-BHC, which might need study as contaminants on the one hand, has been calculated by Gough (1957) on the other hand - because their use permits the wheat bulb fly, the most serious insect pest of British wheat crops, to be suppressed - to have led to the harvesting of an additional 46000 tonnes of wheat, valued at $\oint_{1}$ i00 000 .

The subtle interrelationship between what we in this symposium are discussing as contaminants, nutritional well-being, economics and human natural history was strikingly demonstrated in the Irish famine of $1845-7$. The factors which combined to cause this nutritional disaster were: the destruction of the potato crop by the blight (Phytophthera infestans) the weather, the particular form of social organization then existing in which the landlords enjoyed almost absolute control over their tenants and the economic doctrine under which it was taken that the export from Ireland of cereal grains at a high price during the famine would ameliorate the prosperity of those then suffering from starvation. In the context of our present discussion, Large \& Waines (I96I) have calculated that the treating of main-crop potatoes in Great Britain during the years $1947^{-56}$ with fungicidal sprays based on copper or on dithiocarbamate has avoided an annual loss of $8 \%$ of the crop. Since I95\%, the danger of significant outbreaks of potato blight has been capable of being forecast by the collection of appropriate meteorological data. It would be an elegant refinement if nutritionists, in drawing up rational standards for permissible levels of contaminants in food designed to assure the maximum nutritional benefit to the community, adjusted the level according to the imminence of a so-called 'Beaumont period' in the weather when the danger of potato blight was particularly great. But, while this degree of refinement may not be feasible, it is nevertheless important to take into account the cconomic significance of the use of an additive or of a potential producer of contamination, both in terms of the wealth of the community 
and the production of food as a positive contribution to nutrition to be balanced against any toxicological hazard.

\section{Aesthetics}

According to Van Stuyvenberg (1969), one of the best-known regulations, devised by the dairying interests and designed to hamper the consumption of margarine, was one which was enforced in New Jersey and several other states compelling margarine manufacturers to colour their product pink. There is nothing intrinsically offensive about pink margarine nor is there any nutritional reason, using the term in its biochemical sense, why a fat designed to be spread on bread should be white like lard, as was decreed in subsequent legislation. The evidence is plain, however, that by thus preventing the producers of margarine from manufacturing a yellowcoloured commodity the authorities in the United States of America inhibited many people whose nutritional well-being would have benefited from the consumption of an inexpensive and nourishing commodity from taking advantage of it. Similar regulations were promulgated in Germany and for the same reason, only there a Reichstag Commission wanted margarine to have the brown colour of oak wainscoting whereas other pressure groups favoured a blue colouring for the product. It will be interesting to see whether supporters of the meat trade propose an embargo against the incorporation of artificial brown colouring during the manufacture of simulated meat prepared from spun or extruded soya protein or texturized fungal protein.

The significance of colour in foods and its affect on food acceptance is becoming well known to nutritionists. The fact that it is deeply rooted and certainly goes back as far as the Doctrine of Signatures which, though codified by Paracelcus in the sixteenth century (Arber, I938), derives from primitive antiquity does not make it any less relevant today as is, perhaps, testified by those people who insist on selecting brown-shelled eggs regardless of the fact that they do not eat the shell. Nevertheless, in scrutinizing the marginal toxicological significance of food colours, those concerned with regulating food additives and the preparation of approved lists must bear in mind - and if possible assess on a quantitative basis - their influence on food intake and consequently on health and nutrition.

The significance of colour as a controlling factor in the diet eaten by communities with particular patterns of behaviour is apparent whether the dietary level is ample or scanty. An observation made during practical trials of the administration of a soup comprising an aqueous suspension of a complete vitamin-protein mixture described as Multipurpose Food is relevant. The community being fed were people sheltering from air attack in the London underground railway station at Shepherds Bush in $194^{\circ}$. These people, though hungry, declined to accept the soup as originally presented as a thin, white paste. As soon as it was coloured the shade of brown considered by the consumers to be appropriate for soup, they ate it with avidity. Clearly any assessment of the acceptability of a colour as an additive must take account of its influence on the nutrition of the people for whom the coloured food is designed. 
The classical example of nitrogen trichloride, for a generation used as the flour additive, Agene, illustrates in a different way the balance that needs to be struck in these matters. Once again, the purpose of the additive was aesthetic; to produce a bigger, more uniform and more even-textured loaf of bread. Indeed, to attain $\mathrm{r} .5 \mathrm{~cm}(0.6 \mathrm{in}$.) additional height in a standard load (Horder, Dodds \& Moran, I954) a great deal of difficult technological work was carried out before Agene was developed and appropriate conditions for its use were determined. Combined with the aesthetic desirability of the large, bold loaves there was a parallel economic advantage in that the 'improver', Agene, allowed the increased use of more readily available 'softer' English and European wheats when 'hard', and more expensive Canadian wheats, were unavailable. Hence economics which together with aesthetics exert a significant, although so far unquantified, influence on nutrition, were both factors to be taken into account in balancing the potential, but also unquantified, toxicological dangers to man of the methionine sulphoximine produced by interaction of the Agene with methionine. The reality of the aesthetic importance of loaf size and structure in the acceptance of bread by its consumers is re-emphasized by the prolonged and successful efforts to find appropriate chemical substitutes for Agene among chlorine dioxide, bromate, ascorbic acid, cysteine and others, quite apart from the development by Elton (I966) and his colleagues of the so-called 'Chorleywood process' for the mechanical development of dough.

\section{Social implications of food additives}

Nutritionists whose main preoccupations are with the chemical configurations of the various isomers of vitamins or with the histological changes occurring in the tissues of the genito-urinary tract of a mouse to which massive doses of cyclamates have been administered are sometimes impatient with the vagaries of the dietary patterns of behaviour of communities such as are evidenced by their willing consumption of brown soup and white bread, and their refusal of the same commodites when the colours are reversed. However, when potentially harmful additives or contaminants are involved in the preparation of such products, the simplest solution to the problem set by their presence - that of passing a law to forbid their use - may be unscientific. Thoughtful women troubled by the constant changes in fashions in clothes are equally aware that such changes, like preferences in food, possess a sociological basis and would not be stopped merely by the forcible closure of the Parish fashion houses.

Buzzell \& Nourse (1967) carried out a detailed investigation of every new food product introduced on to the market in the USA during the decade from 1954 to 1964. It was found that these could be divided into three groups. The first comprised those which, regardless of the amount of scientific effort devoted to their perfection or to the amount of money spent on test marketing, packaging and promotion, instantly failed from the moment of their launching. A second group comprised products which after a modest initial success reached a plateau of mediocre acceptance and thereafter faded from the market. There was, however, a third group of products which were immediately and persistently successful. This investigation 
seems to me to raise two points which are relevant to our present discussion. The first is to bring out the somewhat unexpected list of commodities, for example instant potato and pourable salad cream, which became widely accepted as part of a community's diet. The second point is that no food manufacturer, regardless of how powerful, technologically competent or commercially expert, appeared to be able to foresee whether a newly launched product would be popular and successful or would be a failure.

\section{Conclusion}

The evidence summarized in this paper has been designed to show that, if a just assessment is to be obtained of the significance of food additives in the nutritional well-being of the community, the metabolic aspects of food safety provide only part of the answer. To obtain a more complete picture, the economic implications of the use of additives and their influence on the selection of their diet by the community must also be taken into account.

\section{REFERENCES}

Arber, A. (1938). Herbals. London: Cambridge University Press.

Buzzell, R. D. \& Nourse, R. E. R. (1967). Product Innovation in Food Processing 1954-64. Boston, Mass.: Harvard University Press.

Elton, G. M. A. (1966). Br. Baker 152, 47.

Gough, H. C. (1957). Bull. ent. Res. 48, 447.

Horder, T., Dodds, C. \& Moran, T. (ז954). Bread. London: Constable.

Large, E. C. \& Waines, R. A. (1961). Pl. Path. Io, 96.

Laverton, S. (1962). The Profitable Use of Farm Chemicals. London: Oxford University Press.

Orr, J. B. (1936). Food, Health and Income: Report on Survey of Adequacy of Diet in Relation to Income. London: Macmillan.

Public General Acts (1970). Therapeutic Substances Act, 1956, 4 \& 5 Eliz. 2 ch. 25.

Roe, F. J. C. (1970). Metabolic Aspects of Food Safety. Oxford: Blackwell Scientific Publications.

Rowntree, B. S. (1903). Poverty : a Study of Town Life. London: Longmans.

Rowntree, B. S. (I94r). Poverty and Progress. London: Longmans.

Rowntree, B. S. \& Lewens, G, R. (195I). Poverty and the Welfare State. London: Longmans.

Statutory Instrument (1971). Supply of Antibiotics and Chemotherapeutic Substances for Agricultural Purposes Regulations, 1971. Stat Instrum. no. 304.

Swann, M. M. (Chairman) (1969). Foint Committee on the use of Antibiotics in Animal Husbandry and Veterinary Medicine. Report of the Secretary of State for Social Services, the Secretary of State for Scotland, the Minister of Agriculture, Fisheries and Food and the Secretary of State for Wales. [Cmnd 4190]. London: H.M. Stationery Office.

Van Stuyvenberg, J. H. (1969). Margarine : an Economic and Scientific History. Liverpool: Liverpool University Press.

Walters, J. (1971). Poult. Wld May, p. I9.

Wittmann, W., Moodie, A. D., Fellingham, S. A. \& Hansen, J. D. Z. (ז967). S. Afr. med. F. 4r, 664. 